\title{
On the glaciology of Edgeøya and Barentsøya, Svalbard
}

\author{
JULIAN A. DOWDESWELL and JONATHAN L. BAMBER
}

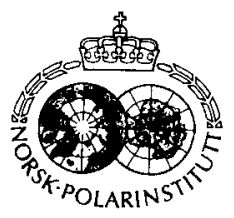

Dowdeswell J. A. \& Bamber, J. L. 1995: On the glaciology of Edgeøya and Barentsøya, Svalbard. Polar Research 14(2), 105-122.

The ice masses on Edgeøya and Barents $\varnothing$ ya are the least well known in Svalbard. The islands are $42-47 \%$ ice covered with the largest ice cap, Edgeøyjøkulen, $1365 \mathrm{~km}^{2}$ in area. The tidewater ice cliffs of eastern Edgeøya are over $80 \mathrm{~km}$ long and produce small tabular icebergs. Several of the ice-cap outlet glaciers on Edgeøya and Barentsøya are known to surge, and different drainage basins within the ice caps behave as dynamically separate units. Terminus advances during surging have punctuated more general retreat from Little Ice Age moraines, probably linked to Twentieth Century climate warming and mass balance change. Airborne radio-echo sounding at $60 \mathrm{MHz}$ along $340 \mathrm{~km}$ of flight track over the ice masses of Edgeøya and Barents $\varnothing y a$ has provided ice thickness and elevation data. Ice is grounded below sea level to about $20 \mathrm{~km}$ inland from the tidewater terminus of Stonebreen. Ice thickens from $<100 \mathrm{~m}$ close to the margins, to about $250 \mathrm{~m}$ in the interior of Edgeøyjøkulen. The maximum ice thickness measured on Barentsjøkulen was $270 \mathrm{~m}$. Landsat MSS images of the two islands, calibrated to in-band reflectance values, allow synoptic examination of snowline position in late July/early August. Snow and bare glacier ice were identified, and images were digitally stretched and enhanced. The snowline was at about $300 \mathrm{~m}$ on the east side of Edge øyjøkulen, and $50-100 \mathrm{~m}$ higher to the west. Snowlines were at approximately $450 \mathrm{~m}$ on Digerfonna and Storskalven. On Barentsjøkulen the snowline was $350 \mathrm{~m}$ above sea level on the eastern flank and over $400 \mathrm{~m}$ on the west. This asymmetry suggests greater precipitation on the east side of the ice caps. Enhanced Landsat imagery was also used to identify suspended sediments in the waters offshore of the islands. Where this turbid meltwater emerges from tidewater glacier termini, it is likely to be derived from the subglacial drainage system. This suggests that at least parts of the beds of the ice masses on Edgeøya and Barentsøya are at the pressure melting point, and that a basal hydrological system is present

Julian A. Dowdeswell, Centre for Glaciology, Institute of Earth Studies, University of Wales, Aberystwyth, Dyfed SY23 3DB. Wales, U.K.; Jonathan L. Bamber, Mullard Space Science Laboratory, Department of Space and Climate Physics, University College London, Holmbury St. Mary, Dorking, Surrey RH5 6NT. U.K.

\section{Introduction}

The eastern and northeastern islands of Svalbard are the most isolated and coldest in the archipelago. Sea ice occurs in the waters of these areas throughout the year, with August and September being the clearest months (Vinje 1985), and shorefast ice is present in less exposed areas during winter and spring. The ice caps and glaciers on the islands of Edgeøya and Barentsøya are the least well known in the archipelago (Fig. 1). By contrast, the large ice caps on Nordaustlandet and Kvitøya to the northeast have been investigated systematically, in terms of their morphology and dynamics (Jonsson 1982; Dowdeswell 1986; Dowdeswell et al. 1986; Dowdeswell \& Drewry 1989; Bamber \& Dowdeswell 1990).

In this paper the contemporary glaciology of the ice caps and outlet glaciers on Edgeøya and Barentsøya is investigated using two forms of remote sensing: airborne radio-echo sounding to measure ice thickness, and Landsat digital satellite imagery to analyse ice surface character and morphology. These datasets, together with the oblique and vertical aerial photograph series obtained by Norsk Polarinstitutt, will be used to outline our existing knowledge of the modern glaciology of Edgeøya and Barentsøya.

An early description of the ice cliffs forming much of eastern Edgeøya (Fig. 2) comes from a visit by James Lamont in 1859 (Lamont 1861). A comprehensive set of oblique aerial photographs of the islands and their ice masses was obtained by Norsk Polarinstitutt in 1936, and several further aerial photograph campaigns have been undertaken in the succeeding years. Based on this information, Lefauconnier \& Hagen (1991) have described the recent fluctuations of tidewater glacier termini on Edgeøya and Barentsøya. Systematic studies of the glaciers and ice caps on 


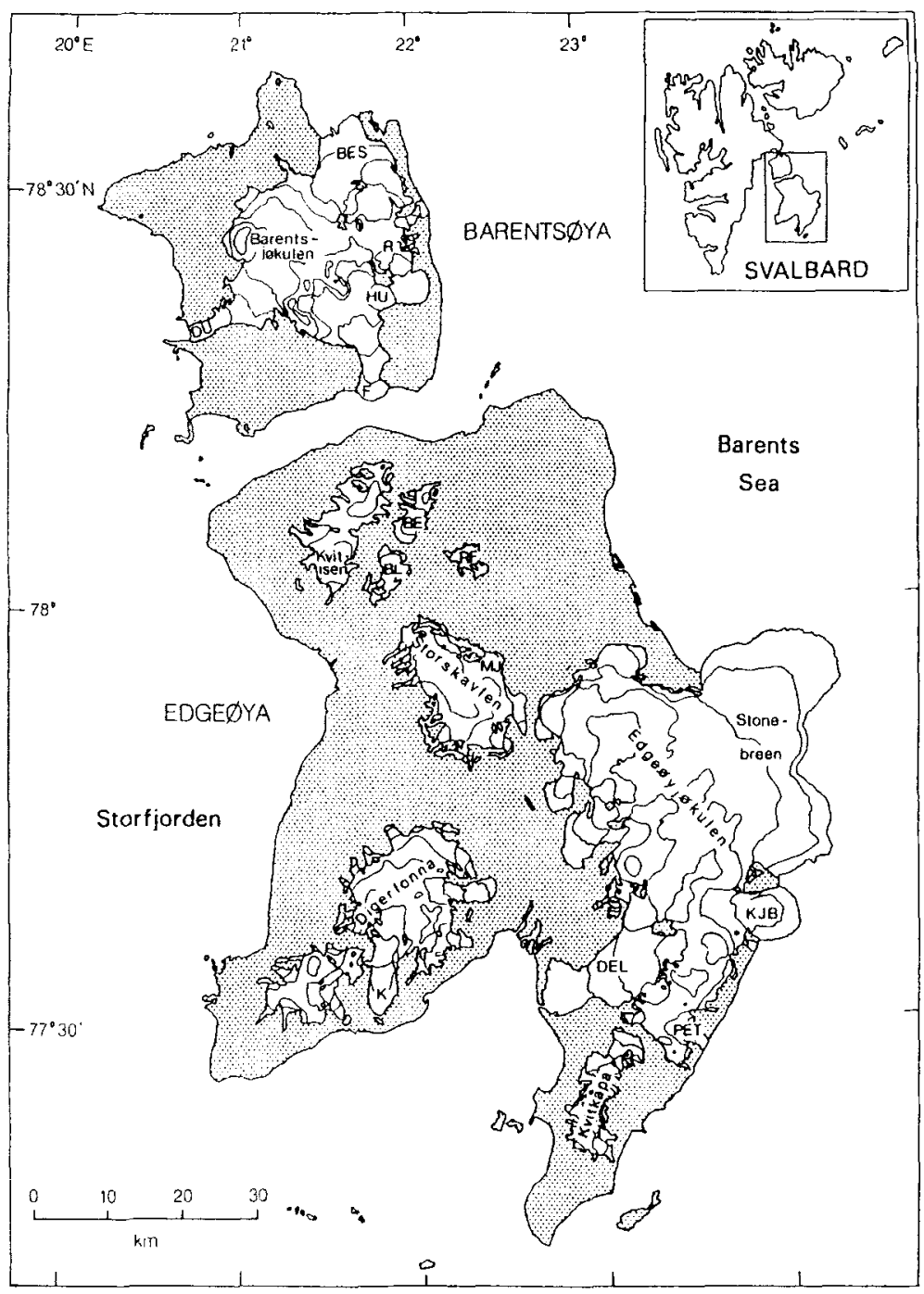

Fig. 1. Edgeøya and Barentsøya, with ice caps and glaciers shown. Contour interval on glaciers is $100 \mathrm{~m}$ (redrawn from Norsk Polarinstitutt 1:500,000 Series Map 2) On Edgeøya, BE is Bergfonna. $\mathrm{BL}$ is Blàisen, DEL is Deltabreen, $K$ is Kuhrbreen, $\mathrm{KJB}$ is Kong Johans Bre. MJ is Marsjøbreen and PET is Pettersenbreen. On Barentsøya, BES is Besselsbreen, $F$ is Freemanbreen, DU is Duckwitzbreen, HU is Hübnerbreen and $\mathrm{R}$ is Reymondbreen. The location of the islands within the Svalbard archipelago is inset.

the two islands are otherwise unavailable. Our existing knowledge of the distribution and topography of the ice masses on Edgeøya and Barentsøya is outlined, together with information on glacier surges and terminus fluctuations. before attention is turned to airborne and satellite remote sensing investigations.

\section{Ice extent and surface topography on Edgeøya and Barentsøya}

The islands of Edgeøya and Barentsøya are $42 \%$ and $47 \%$ ice covered, respectively (Table 1 ). The $2200 \mathrm{~km}^{2}$ of ice cover on Edgeøya contains several ice caps (Fig. 1), the largest of which are
Edgeøyjøkulen $\left(1365 \mathrm{~km}^{2}\right)$, Digerfonna $(270$ $\left.\mathrm{km}^{2}\right)$ and Storskavlen $\left(190 \mathrm{~km}^{2}\right)$. The surface morphology of these ice caps and associated outlet glaciers is complex, and maximum elevations range between $530 \mathrm{~m}$ and $590 \mathrm{~m}$. The eastern outlet glaciers of Edgeøyjøkulen form a relatively long length of tidewater ice cliffs, protruding into the shallow offshore waters of the northwestern Barents Sea (Fig. 2). Taken together with the lagoonal ice cliffs of Deltabreen (Fig. 1), there are about $90 \mathrm{~km}$ of ice-ocean interface on Edgeøya from which icebergs, meltwater and sediments can be released directly into marine waters. Tabular icebergs up to about $100 \mathrm{~m}$ in length have been observed both adjacent to and 
Fig. 2. The eastern coast of Edgeøya (Fig. 1) from 1936 oblique aerial photography (S36 3480). The photograph shows the tidewater terminus of Pettersenbreen in the foreground, and Kong Johans Bre and

Stonebreen, descending from Edgeøyjøkulen, in the background (up to $40 \mathrm{~km}$ distant). Note the crevassing on

Pettersenbreen, and the highly disturbed surface of Kong Johans Bre. Turbid meltwater plumes are visible in the marine waters, derived from proglacial and subglacial sources.

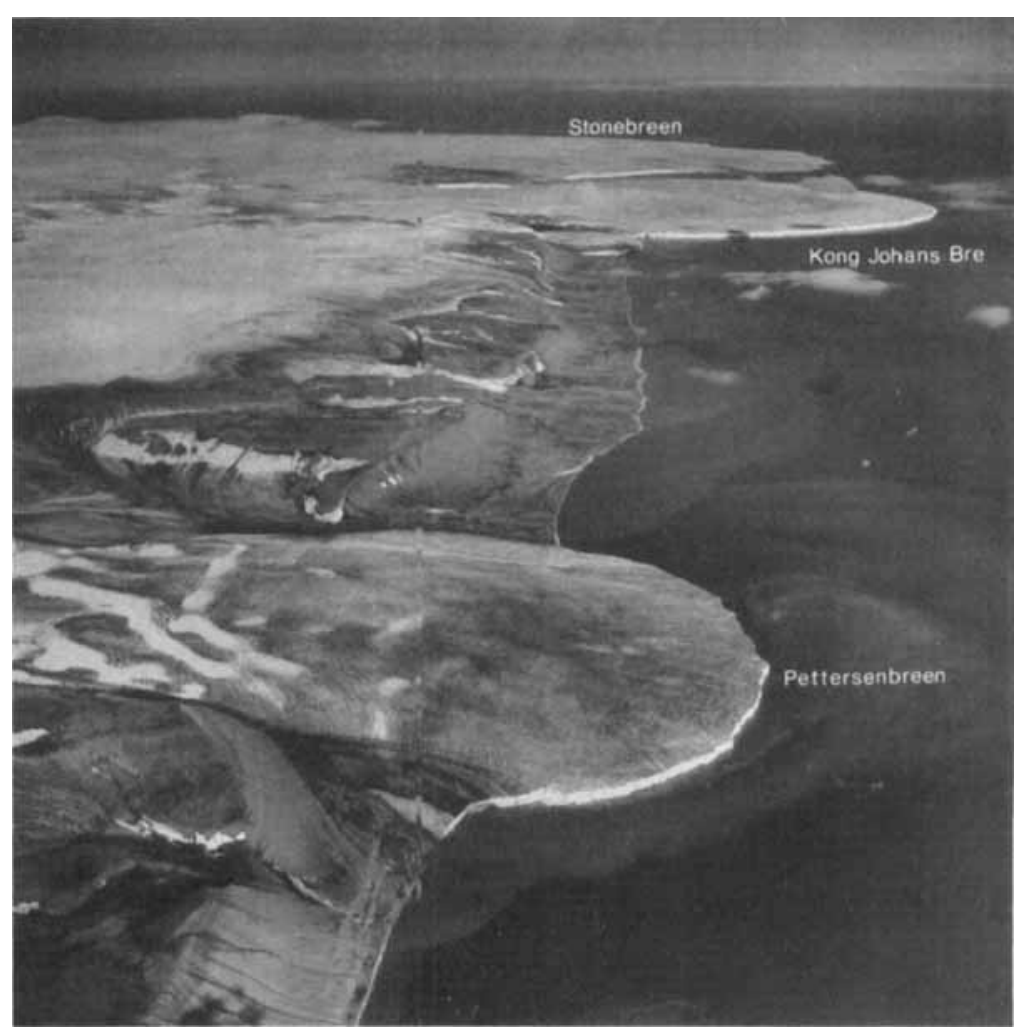

within a few kilometres of these ice cliffs, apparently grounded in relatively shallow water (Dowdeswell 1989).

Barentsøya has a glacierised area of $610 \mathrm{~km}^{2}$ made up of a single, but topographically complex, ice cap named Barentsjøkulen (Fig. 1). The ice cap reaches a maximum altitude of $665 \mathrm{~m}$ and is drained by a number of outlet glaciers, of which Freemanbreen, Duckwitzbreen and Besselsbreen are among the largest (Fig. 1). The tidewater ice cliffs of these outlet glaciers make up an iceocean, interface approximately $12 \mathrm{~km}$ long (Table 1). Lefauconnier \& Hagen (1991) note that Duckwitzbreen no longer ends in tidewater, and is now building a moraine system above sea level.

The ice margins and surface topography of the ice masses on Edgeøya and Barentsøya have been mapped by members of Norsk Polarinstitutt from vertical aerial photographs and associated ground control points. Norsk Polarinstitutt maps at scales

Table I. The dimensions of the ice masses on Edgeøya and Barentsøya, with those of the other main islands of the Svalbard archipelago given for comparison. Sources: Dowdeswell 1989; Hagen el al. 1993; Bamber \& Dowdeswell 1990.

\begin{tabular}{lcccr}
\hline Island & $\begin{array}{l}\text { Total area } \\
\left(\mathrm{km}^{2}\right)\end{array}$ & $\begin{array}{l}\text { Ice-covered } \\
\text { area }\left(\mathrm{km}^{2}\right)\end{array}$ & $\begin{array}{l}\text { Percentage } \\
\text { ice-covered }\end{array}$ & $\begin{array}{c}\text { Length of ice } \\
\text { cliffs }(\mathbf{k m})\end{array}$ \\
\hline Edgeøya & 5160 & 2194 & 42 & 80 \\
Barentsøya & 1298 & 610 & 47 & 12 \\
Spitsbergen & 39170 & 21805 & 55 & 485 \\
Nordaustlandet & 14997 & 11262 & 75 & 305 \\
Kvitøya & 710 & 705 & 69 & 105 \\
Kong Karls Land & 345 & 22 & 6 & 0 \\
\hline
\end{tabular}



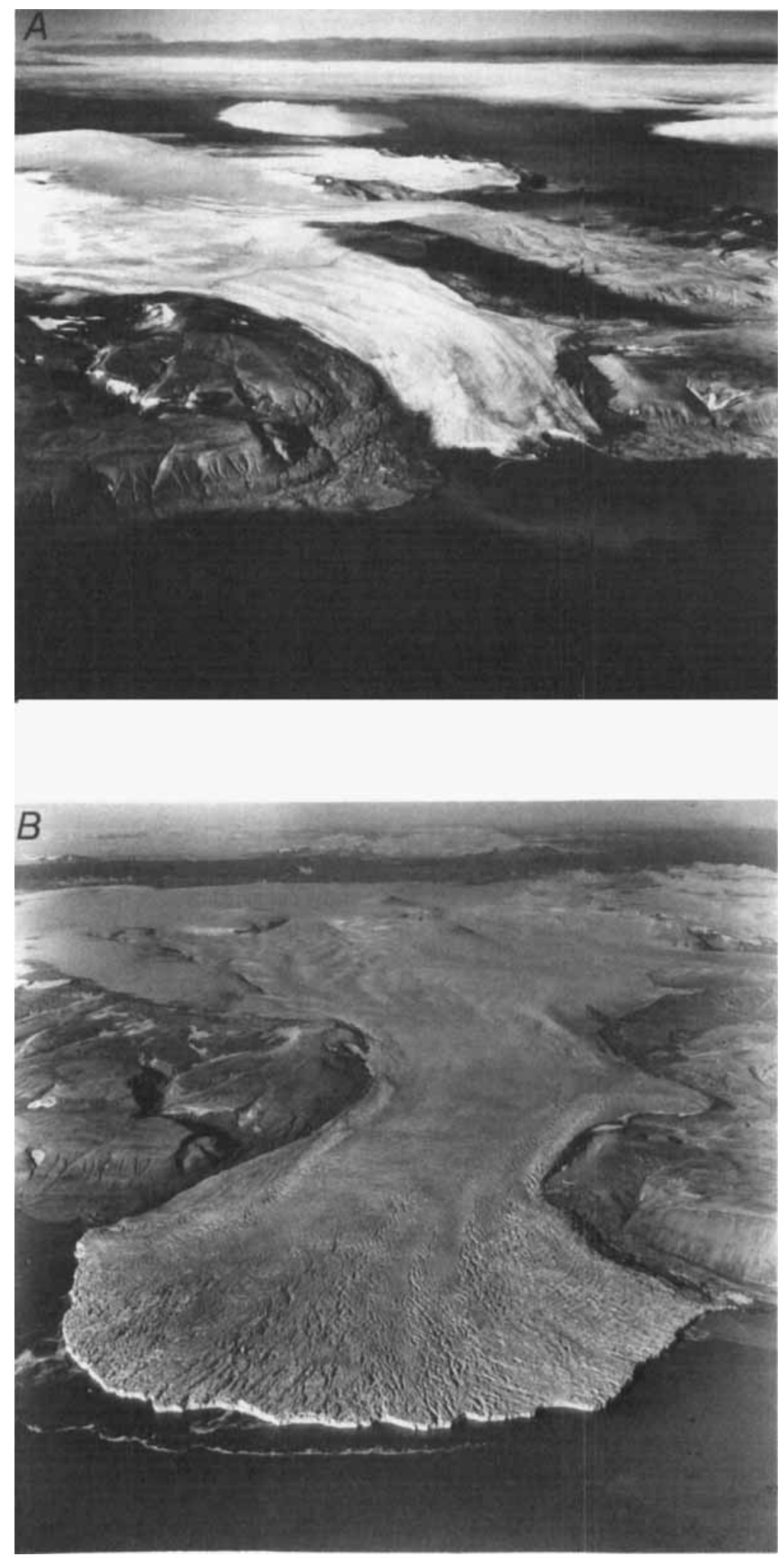

Fig. 3. The tidewater glacier Freemanbreen, Barentsøya (Fig. 1), photographed at different stages of a surge cycle. (A) From 1936 oblique aerial photography (S36 3842), in the quiescent phase with little surface crevassing. (B) From 1956 oblique photography (S56 1393), during the active phase with heavy surface crevassing. Note the terminus advance significantly beyond the coastline and the 1936 ice front position. (C) In 1970, from a vertical aerial photography (S70 4568).

The glacier still protrudes beyond the coast. but crevasses are closed up and the ice is largely stagnant. 
Fig. 3. Continued.

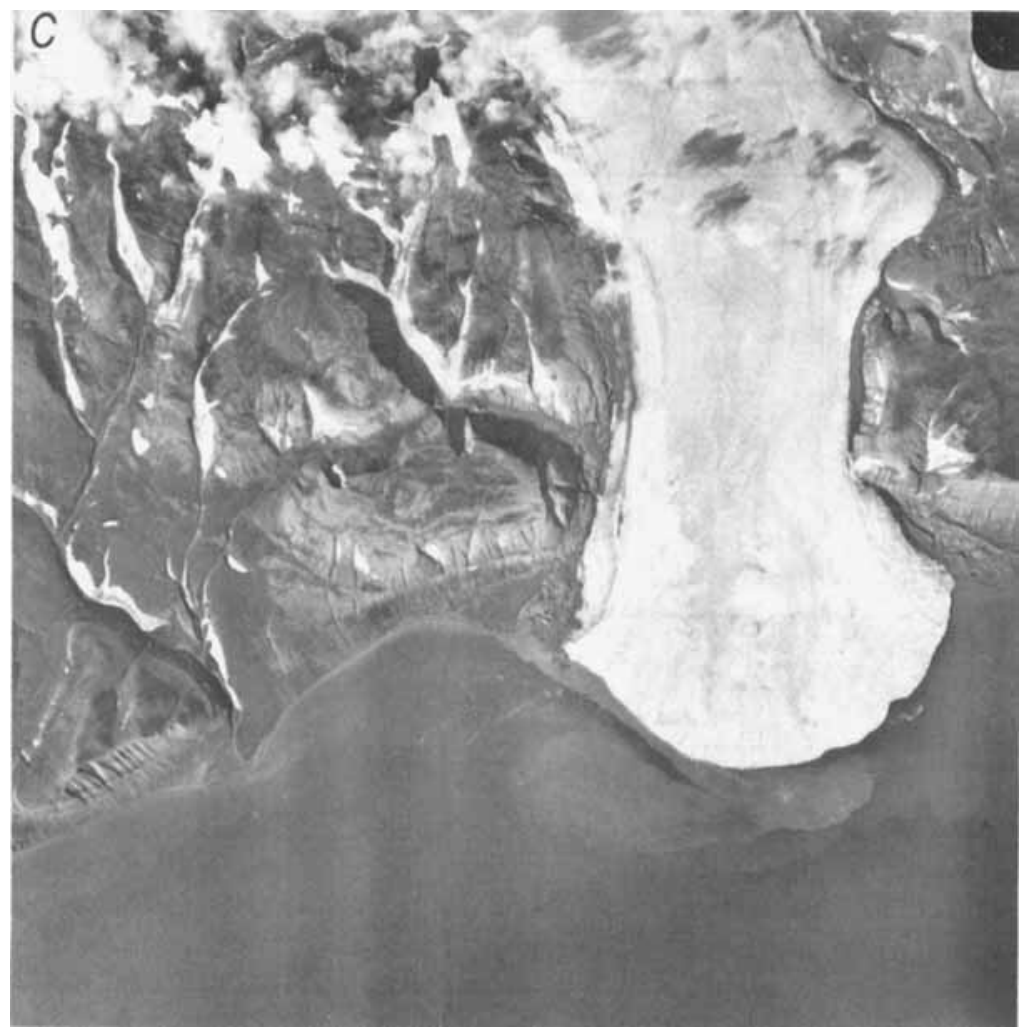

of $1: 500,000(1988)$ and $1: 100,000(1993)$ provide baseline data on elevations and areas for the ice caps on the two islands (Hagen et al. 1993).

\section{Surge-type glaciers and glacier terminus fluctuations}

Several of the ice caps on Edgeøya and Barentsøya are interpreted to be of surge-type (Table 2 ), based on a combination of direct observations and analysis of vertical and oblique aerial photographs (Liestøl 1993). Such ice masses exhibit cyclical instabilities in the form of short phases of rapid motion, often a few years in duration in Svalbard (Dowdeswell et al. 1991). The surges, with associated surface crevassing and terminus advance, punctuate significantly longer periods of quiescence and stagnation. A series of aerial photographs of Freemanbreen, southern Barentsøya (Fig. 1), illustrates the changing character of a surge-type glacier prior to, during, and after the active phase (Fig. 3).
The analysis of early reports and maps, together with the availability of systematic aerial photography since 1936, shows two types of glacier terminus behaviour. The first is terminus advance, presumably rapid, associated with the active phase of the surge cycle. The second is a more general retreat from moraine systems probably dating from a Little Ice Age maximum, linked to changing environmental conditions and, in some cases, to stagnation during the quiescent phase of the surge cycle. Prominent moraine ridges, sometimes protruding beyond the line of the coast where tidewater glaciers are present, mark the recent extent of these ice masses.

On Barentsøya, Duckwitzbreen and Freemanbreen have been retreating since surges and accompanying advance at about 1918 and 1956, respectively (Liestøl 1993). However, surges of Hübnerbreen and Reymondbreen, recorded on 1936 and 1956 aerial photographs (Table 2), did not result in terminus advance. These glaciers appear to have surge activity superimposed upon 
Table 2. Known surge-type glaciers on Edgeøya and Barentsøya, including their area, length and approximate date of last surge. See Fig. 1 for locations. Sources: Liestøl 1993; Hagen et al. 1993.

\begin{tabular}{lrrr}
\hline Island and glacier & $\begin{array}{c}\text { Area } \\
\left(\mathrm{km}^{2}\right)\end{array}$ & $\begin{array}{l}\text { Length } \\
(\mathbf{k m})\end{array}$ & Date of surge \\
\hline Edgeøya & & & ca 1965 \\
SW Kvitkåpa & 13.7 & 4.5 & 1936 \\
E Kvitisen & 5.4 & 4.5 & 1930 \\
SE Bergfonna & 8.6 & 3.5 & between 1936 and 71 \\
Marsjøbreen, Storskavlen & 36.6 & 8.7 & between 1936 and 71 \\
Stonebreen & 711.7 & 33.5 & between 1925 and 30 \\
Kong Johans Bre & 106.8 & 16.0 & ca 1925 \\
Pettersenbreen & 29.2 & 7.0 & $1955-56$ \\
Barentsøya & 96.0 & 19.0 & 1918 \\
Freemanbreen & 98.1 & 19.6 & 1956 \\
Duckwitzbreen & 33.0 & 9.0 & between 1930 and 36 \\
Reymondbreen & 53.2 & 15.0 & \\
Hübnerbreen & & & \\
\hline
\end{tabular}

more general retreat from Little Ice Age maxima indicated by preserved moraine systems. It is difficult to establish whether these previous maxima were associated with former surges. In the north of the island, Besselsbreen and Augnebreen have shown continuous retreat apparently unpunctuated by surge activity since an assumed Little Ice Age maximum extension (Lefauconnier \& Hagen 1991).

For Edgeøya, Lefauconnier \& Hagen (1991) provide details on marginal fluctuations of those ice masses ending in or close to tidewater. Lamont (1861) reported the approximate position of several of the ice fronts on the east coast in 1859 . Hartmannbreen and Pettersenbreen both protruded about $2.5 \mathrm{~km}$ beyond the line of the coast at this time. Hartmannbreen has retreated continuously since then, whereas Pettersenbreen readvanced during a surge prior to the acquisition of oblique aerial photographs in 1936 (Fig. 2), and has continued to retreat since that time. For the larger ice masses of Kong Johans Bre and Stonebreen to the north (Figs. 1 and 2), it is more difficult to interpret the observations of Lamont due to the relative lack of fixed points, as opposed to ice cliffs, on the coast. However, Lamont reported that the central portion of Stonebreen was very heavily crevassed for a number of kilometres inland, which is interpreted by Lefauconnier \& Hagen (1991) to represent a surge. The northern lobe of Stonebreen appears to have surged between 1936 and 1971. indicating that different basins within this ice cap behave as dynamically separate units. This is similar to the documented behaviour of the drainage basins on the larger ice caps of Austfonna and Vestfonna on Nordaustlandet to the north (Dowdeswell 1986; Dowdeswell \& Collin 1990). Kong Johans Bre appears heavily crevassed on 1936 aerial photographs (Fig. 2), and the glacier probably began to surge sometime in the previous decade (Lefauconnier \& Hagen 1991).

With the exception of these surge-related advances, the tidewater ice masses of eastern Edgeøya have been in retreat over the Twentieth Century, and mapping by Norsk Polarinstitutt shows a measured retreat of $1-1.5 \mathrm{~km}$ in the tidewater ice cliffs of Stonebreen between aerial photograph series acquired in 1971 and 1990. Deltabreen, on the southern coast of Edgeøya (Fig. 1). was described by Lamont (1861) as already being detached from the large moraine which now forms a lagoon at its margins. He noted vegetation growth on the inner part of the moraine, indicating that it had already been stable for some years prior to his visit. Since then retreat has continued and the ice front has now retreated some $5 \mathrm{~km}$ from this moraine system. This evidence could be interpreted to indicate a relatively early termination to the Little Ice Age in southeastern Svalbard, but Lefauconnier \& Hagen (1991) point out similarities in moraine morphology between Deltabreen and a known surgetype glacier. Usherbreen in Spitsbergen (Hagen 
1987), which may suggest that its maximum extent prior to 1859 was surge related.

Climatically-induced changes in mass balance are likely to be responsible for the retreat of many glaciers in Edgeøya and Barentsøya over the period for which we have observational records of glacier terminus fluctuations. The relationship between climate and glacier fluctuations is not a simple one, however, and variable lags in glacier response, the hypsometry of individual glacier systems, and the offshore bathymetry in the case of tidewater glaciers, are several of the factors that make glacier-climate links complex. Meteorological evidence from Spitsbergen shows that the climate has warmed by several degrees since the early Twentieth Century (Fig. 4A), and mass balance data obtained from several glaciers in Spitsbergen since the 1950s (Hagen \& Liestøl $1990)$ demonstrate that ice masses in these areas have been subject almost exclusively to negative balances (Fig. 4B). If this pattern is similar to that

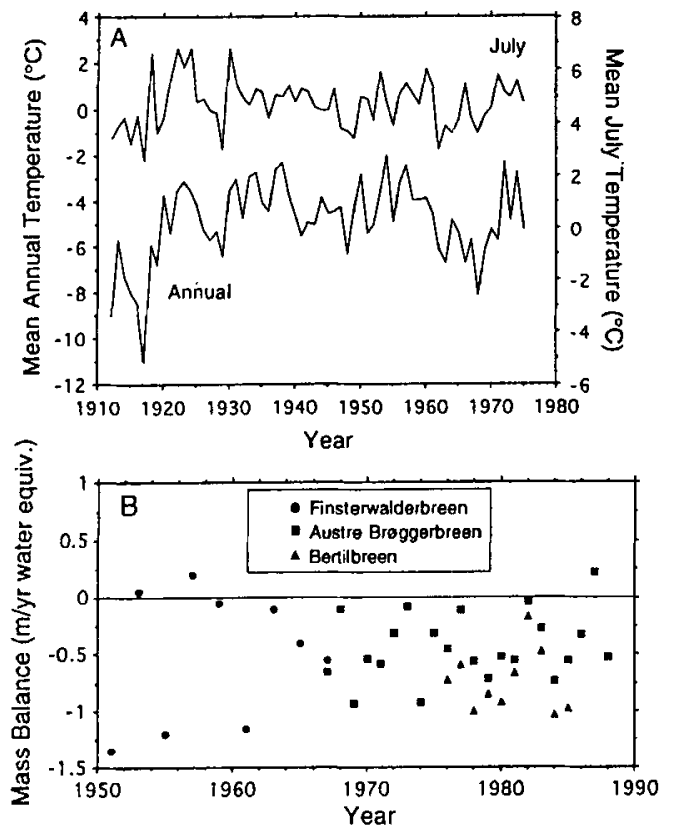

Fig. 4. Twentieth Century climate and glacier mass balance data from Spitsbergen, the largest island in the Svalbard archipelago (Fig. 1). (A) Temperature time series from Spitsbergen meteorological records since 1911, showing mean annual air temperature and mean July air temperature. (B) Mass balance measurements from three Spitsbergen glaciers since $1950(n=$ 43 sets of observations). Sources: Hagen \& Liestøl (1990): J. O. Hagen, pers. comm. in the eastern islands of Edgeøya and Barentsøya, where no mass balance measurements have been made, then the trend towards glacier recession over the last century or so can be explained by a shift towards warmer conditions and negative glacier mass balance since the termination of the Little Ice Age.

\section{Remote sensing data acquisition and methods}

\section{Airborne radio-echo sounding}

Airborne radio-echo sounding of the glaciers and ice caps of Edgeøya and Barentsøya took place from a de Havilland Twin Otter aircraft, operated from the airport at Longyearbyen, about $140 \mathrm{~km}$ west of Barentsjøkulen and $200 \mathrm{~km}$ from Edgeøyjøkulen. Two dedicated radio-echo sounding flights were undertaken in May 1986, and $340 \mathrm{~km}$ of radio-echo sounding track lines were acquired.

Radio-echo sounding (RES) data were obtained using a SPRI Mk. IV sounder operating at a centre frequency of $60 \mathrm{MHz}$. The system had a pulse length of $300 \mathrm{~ns}$, a system performance of $160 \mathrm{~dB}$ (including mis-match losses but excluding antenna gain), and a theoretical forward gain of $8.3 \mathrm{~dB}$. The antennae used were two half wave dipoles located beneath the aircraft wings, one to transmit and the other to receive. The geometric mean of eight individual waveforms, each comprising 256 samples taken at $100 \mathrm{~ns}$ intervals, was recorded digitally. A detailed account of the digital recording system is found in Gorman \& Cooper (1987). Data were also recorded in analogue " $Z$ " scope form using an oscillograph and heat sensitive paper. An example of this type of record is shown in Fig. 5, and shows the hyperbola associated with the tidewater ice cliffs of Edgeøyjøkulen, and the ice thickening inland from this coastal crossing. Ice-surface elevation changes were tracked automatically, but for the weaker, noisier and more intermittent bed echoes this was not possible. Instead, a power-differentiated continuous display, produced from the digital data, or, in some cases, the oscillograph output, was digitised manually. The errors in depth measurement incurred are negligible in comparison to the digital sampling length (equivalent to $8.4 \mathrm{~m}$ in ice, which defines the maximum resolution of an individual pulse). 


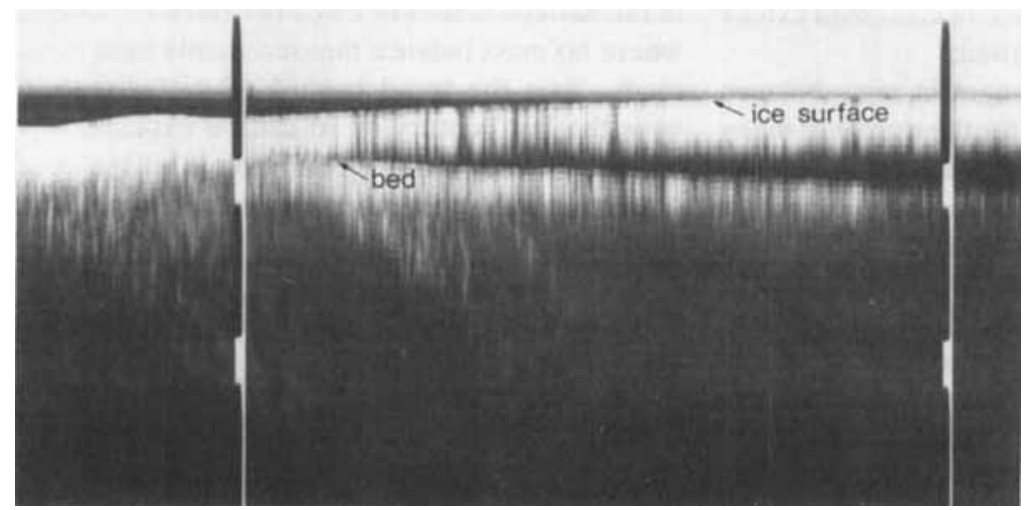

Fig. 5. Analogue radioecho sounding record from Stonebreen. Edge фya (transect located in Fig. 6). The ice surface and bed can be seen, along with the calibration marks on the radio-echo record. This analogue dataset was used as a back-up to a digital data acquisition system.

Radio-echo sounding flights took place at a nominally constant pressure altitude of between 750 and $1000 \mathrm{~m}$. Absolute elevations were calculated using terrain clearance from the radar sounder and a pressure altitude calibrated by overflying areas of open water. Interpolation between pulses enabled the relative surface elevation to be found to within $2 \mathrm{~m}$ (Dowdeswell 1984). The absolute error, however, depended on the distance from the coastal crossing and could rise to $\pm 5 \mathrm{~m}$ near the end of an overland flight segment. Ice thicknesses were calculated using a mean value for the permittivity of ice of 3.17 (equivalent to an em velocity of $168 \mathrm{~m} \mathrm{ss}^{-1}$ in ice).

Navigation was carried out using a combination of a Tactical Airborne Navigation System (TANS), a doppler positioning system, and coastal crossing points. The across track errors depended on the uniformity of the coastline and were typically $\pm 500 \mathrm{~m}$. Along-track errors were, in general, less than $200 \mathrm{~m}$.

\section{Landsat digital satellite imagery}

Three Landsat Multispectral Scanner (MSS) scenes imaging Edgeøya and Barentsøya were acquired in digital form. The Landsat path/row identifiers (World Reference System 1) of the scenes are as follows: $225 / 004$ from 1 July 1980. 226/004 from 29 July 1980. and 229/003 from 1 August 1980. Each image covers an area of $185 \mathrm{~km}$ by $185 \mathrm{~km}$. The Landsat MSS has a nominal resolution of $79 \mathrm{~m}$ by $56 \mathrm{~m}$, and digital data are recorded as relative brightness levels in four spectral bands at visible and near infra-red wavelengths. Digital image processing, to enhance specific glaciological features on the ice caps of the two islands, took place on a Sun-based system in Cambridge.

In order to take a consistent approach to the identification of the snowline on each MSS scene, the Landsat relative pixel brightness data were converted to absolute physical values using MSS instrument calibrations (Markham \& Barker 1986) and algorithms given in Robinove (1982). The algorithms used transform the raw brightness values (Dn) into reflectance or in-band spectral albedo. First, the Dn values are calibrated for drift in MSS detector sensitivity or electronic gain with time. The dynamic range $\left(\operatorname{Lmax}_{1}-\mathrm{Lmin}_{1}\right)$ is calibrated for each detector in each MSS band before satellite launch, and can be used to convert Dn values to spectral radiance, $L_{1}$ in units of $\mathrm{mW} \mathrm{cm}^{-2}$ steradian $^{-1}$, through the equation:

$$
\mathrm{L}_{\hat{\lambda}}=\mathrm{L} \min _{\lambda}+\left(\frac{\mathrm{L} \max _{\lambda}-\mathrm{L} \min _{\lambda}}{\mathrm{Qcal} \max }\right) \cdot \text { Qcal }
$$

where $\operatorname{Lmin}_{1}$ is spectral radiance at Qcal $=0$, $\mathrm{Lmax}_{1}$ is spectral radiance at Qcal max and Qcal $\max$ is the maximum value of the calibrated $\mathrm{DN}$ values. Secondly, radiance values were corrected for the effects of atmospheric haze, which scatters light into the cone imaged by the satellite, on the assumption that dark areas of each image (e.g. open water, shadow) represented zero radiance, and that any measured radiance in such areas was due to haze. Finally, conversion from radiance to reflectance was intended to remove the effects of sun elevation (i.e. the solar radiation incident on the surface at the time of imaging), which varies 
through the year. Here, at-satellite reflectance in any MSS band is:

$$
\rho_{\mathrm{p}}=\frac{\pi \mathrm{L}_{\text {in-band }} \mathrm{d}^{2}}{\text { Esun }_{\text {in-band }} \cos \theta_{\mathrm{s}}}
$$

where $\rho_{\mathrm{p}}$ is effective at-satellite in-band planetary reflectance or albedo (\%), $\mathbf{L}_{\text {in-band }}$ is in-band radiance at sensor $\left(\mathrm{mW} \mathrm{cm}^{-2} \mathrm{ster}^{-1}\right)$ calculated using equation 1, $\mathrm{d}$ is Earth-Sun distance in astro-

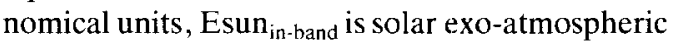

irradiance $\left(\mathrm{mW} \mathrm{cm}^{-2}\right)$, and $\theta_{\mathrm{s}}$ is solar zenith angle. The result of applying these algorithms is that each pixel is assigned an absolute physical value for reflectance. This correction procedure makes the process of classification by ice or snow surface type using a variety of spectral classificatory routines relatively straightforward. The corrected MSS images of Svalbard were then classified into ice and snow zones, in order to locate the late summer snowline.

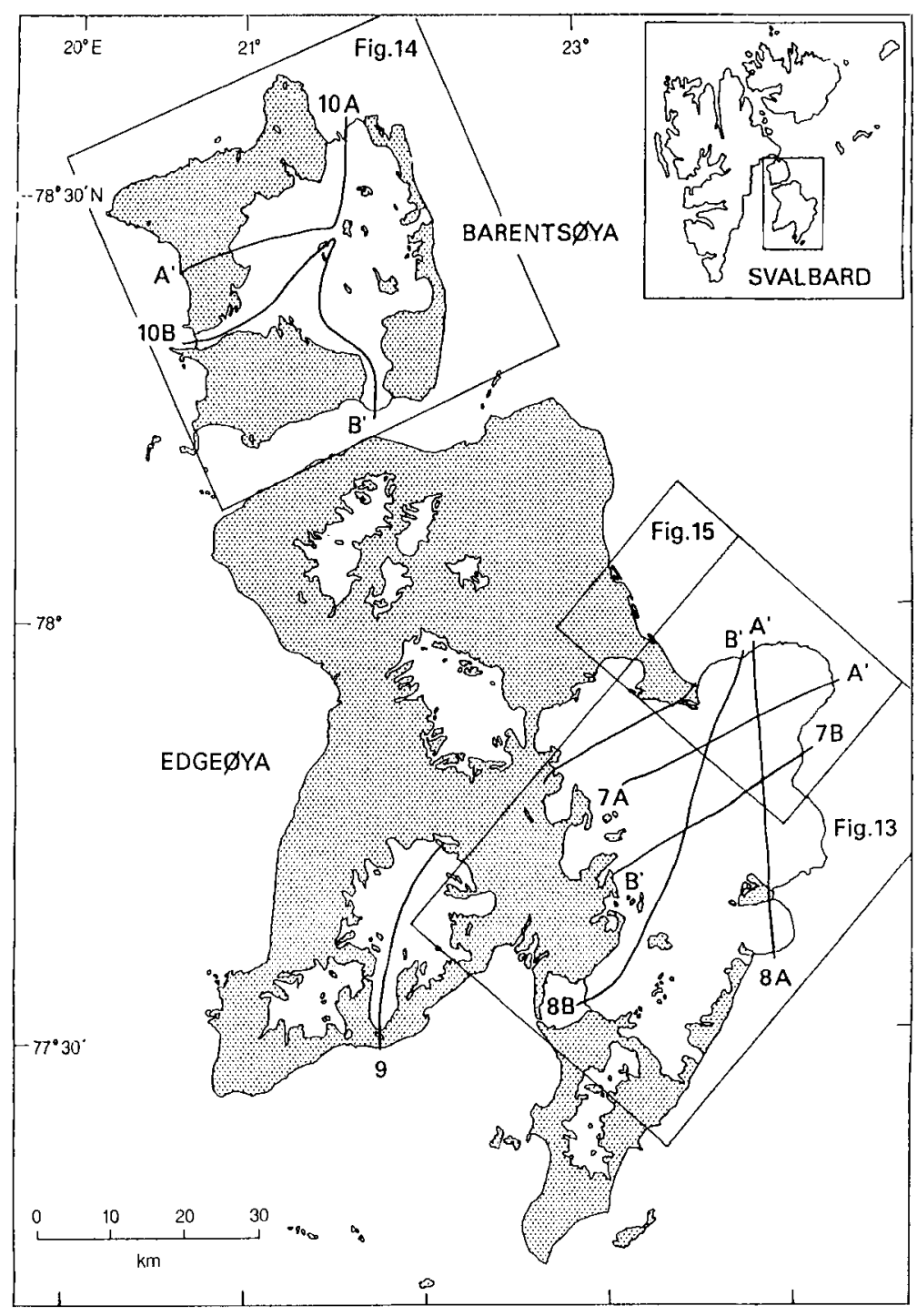

Fig. 6. Radio-echo sounding flight lines on the ice caps of Edgeøya and Barentsøya, Svalbard. The locations of the transects in Figs. 7-10 are shown, along with the satellite images in Figs. 13-15. 


\section{Radio-echo sounding of ice cap thickness}

\section{Edgeøyjøkulen and Digerfonna}

The thickness of the ice cap on Edgeøyjøkulen was investigated along five radio-echo sounding profiles (Fig. 6). As well as traversing the major eastern tidewater glacier system of Stonebreen and its ice cap interior, a profile was taken along the westward flowing outlet glacier, Deltabreen, and across the outer part of Kong Johans Bre (Fig. 1).

Four radio-echo sounding transects run across Stonebreen and the interior of Edgeøyjøkulen, and a further profile crosses the ice cap north of this large outlet glacier (Fig. 6). Two profiles provide ice thickness data along approximate flowlines from the tidewater margins of Stonebreen to the crest of Edgeøyjøkulen (Fig. 7). Both profiles demonstrate that the glacier bed is below sea level for a considerable distance inland from the present terminus. A maximum depth of $100 \mathrm{~m}$ below sea level is recorded (Fig. 7A). Two additional transects provide nominal cross-profiles of Edgeøyjøkulen, although they cut ice flowlines at oblique angles (Fig. 6). The outer profile runs across Stonebreen between 5 and $10 \mathrm{~km}$ from the coast (Fig. 8A). Almost all of the bed along this transect is close to or below sea level, by up to $20 \mathrm{~m}$. The inner profile runs obliquely across Stonebreen, and over the crest of Edgeøyjøkulen, before descending down the outlet glacier Deltabreen (Fig. 8B).

Deltabreen is an outlet glacier of Edgeøyjøkulen which extends just over $30 \mathrm{~km}$ in length, and terminates in moraines adjacent to a lagoon (Lefauconnier \& Hagen 1991). This lagoon is, in turn, almost completely dammed by an older outer moraine (Fig. 6). The outer $4 \mathrm{~km}$ of the glacier has a bed close to or just below sea level, reaching a maximum depth of $-20 \mathrm{~m}$ (Fig. 8B). The outer part of Kong Johans Bre was also sounded by a single cross-profile (Fig. $8 \mathrm{~A}$ ).

A single radio-echo sounding profile was flown over Digerfonna, the second largest ice cap on Edgeøya (Fig. 6). These data show a gradually increasing ice thickness from $120 \mathrm{~m}$ near the terminus of the outlet glacier Kuhrbreen to $370 \mathrm{~m}$ at $12 \mathrm{~km}$ inland (Fig. 9). Thereafter the $60 \mathrm{MHz}$ radar system records no bed echo return. This loss of the bed return is a phenomenon encountered in the interior of a number of glacier and ice cap
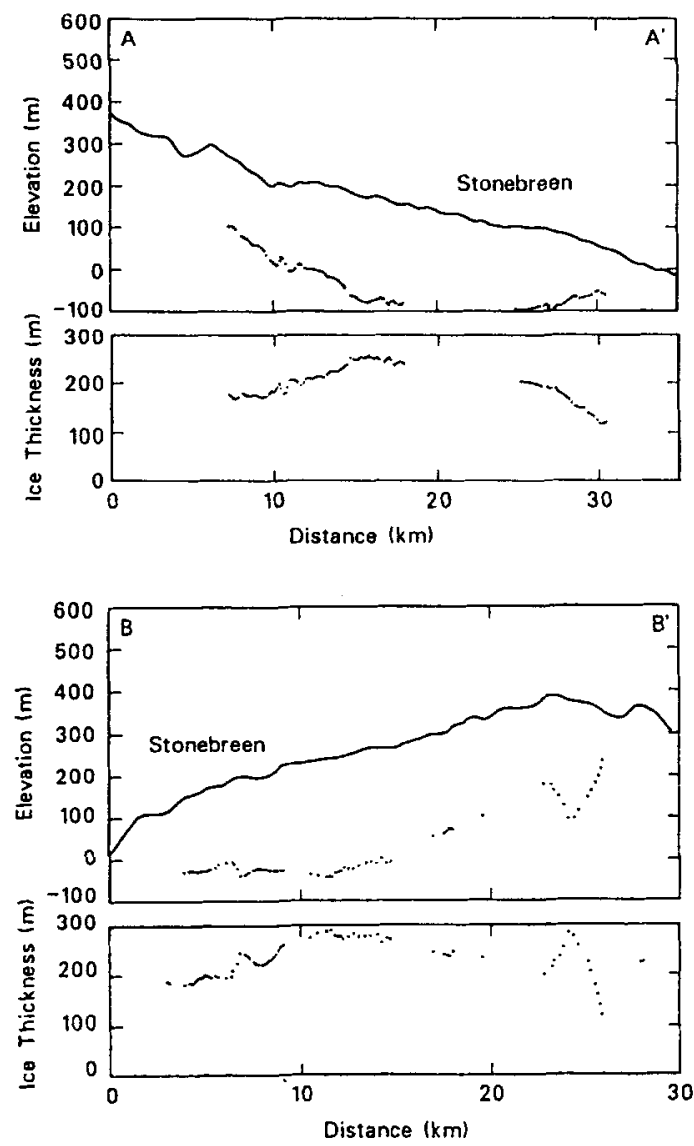

Fig. 7. Radio-echo sounding profiles along two nominal flowlines on Edgeoyjokulen (located in Fig. 6). (A) More northerly transect. (B) More southerly transect. The elevations of the ice surface and bed are shown.

accumulation areas in Svalbard (Dowdeswell et al. 1984). It has been ascribed to the presence of large numbers of scatterers in the snow and firn, due to melting and refreezing effects, combined with relatively warm ice temperatures due to the release of latent heat when refreezing takes place (cf. Schytt 1969). These effects combine to place the radio-echo signal returned from the glacier bed below the noise level of the system, and the bed echo cannot therefore be identified (Dowdeswell et al. 1984).

\section{Barentsjøkulen}

Two radio-echo sounding profiles cross the ice cap of Barentsjøkulen (Fig. 6). The first runs from 

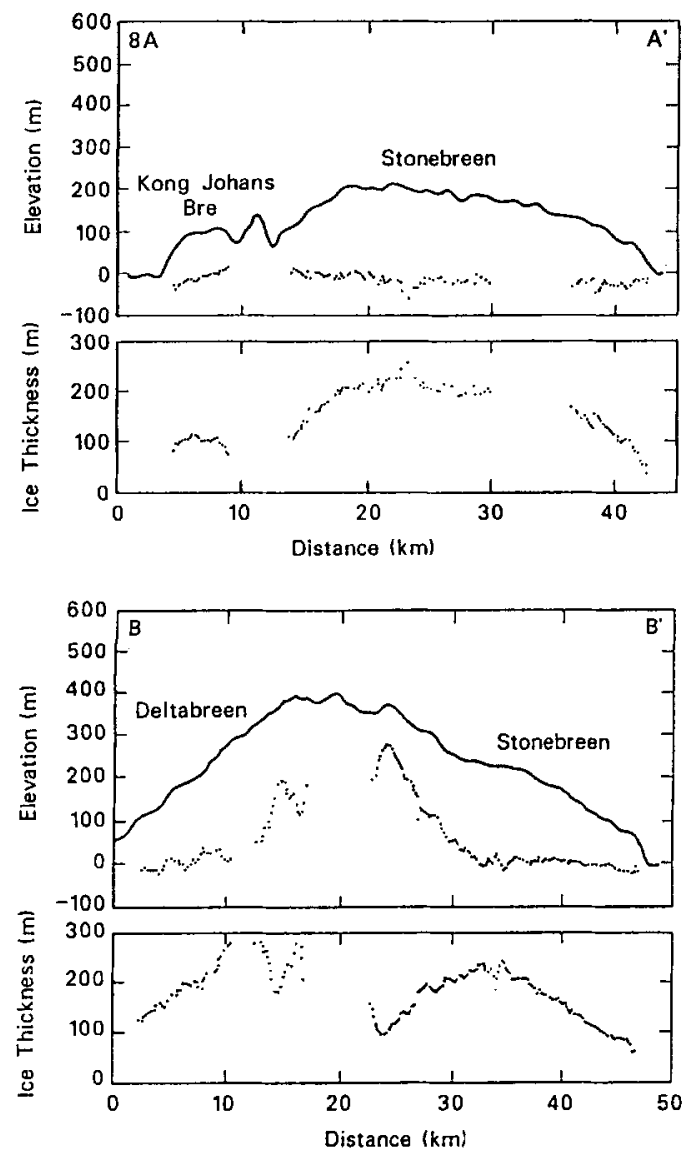

Fig. 8. Radio-echo sounding profiles transverse to flow on Edgeøyjøkulen (located in Fig. 6). (A) A cross-profile across Stonebreen and Kong Johans Bre (Fig. 3). (B) A cross-profile of Stonebreen and a long profile of Deltabreen (Fig. 6). The elevations of the ice surface and bed are shown.

the tidewater margins of Besselsbreen to the ice dome which, at $665 \mathrm{~m}$, forms the highest point on the ice cap (Fig. 10A). The lowermost $4 \mathrm{~km}$ of Besselsbreen is below sea level by up to $40 \mathrm{~m}$, and the maximum thickness of the outlet glacier is $150 \mathrm{~m}$. The ice dome at the head of Besselsbreen has the greatest ice thickness recorded on Barentsøya, at $270 \mathrm{~m}$ (Fig. 10A). A second radioecho profile runs from the outlet glacier Duckwitzbreen into the centre of Barentsjøkulen, before turning southwards down Freemanbreen (Fig. 10B). The beds of both these glaciers lie predominantly above sea level, but it should be noted that no radio-echo sounding data were obtained close to the margin of the tidewater

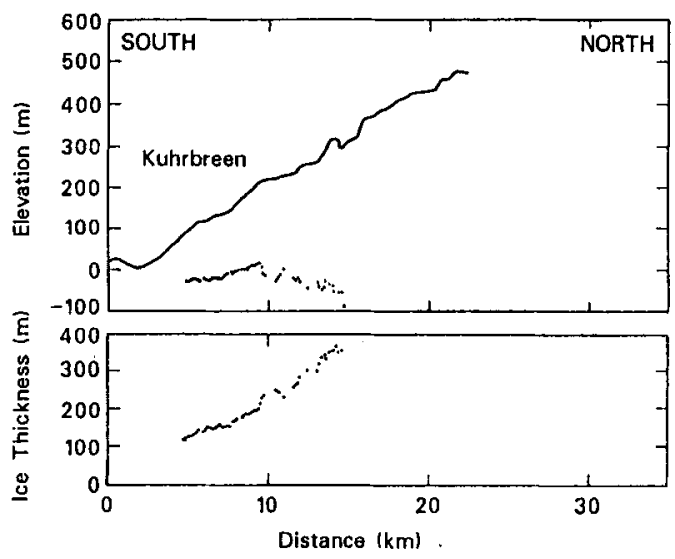

Fig. 9. Radio-echo sounding profile approximately parallel to flow on Digerfonna, with bed returns from the outlet glacier Kuhrbreen (located in Fig. 6). The elevations of the ice surface and bed are shown.

terminus of Freemanbreen. These two outlet glaciers each reach a maximum ice thickness of close to $150 \mathrm{~m}$, and the broader ice cap interior feeding Duckwitzbreen has a maximum recorded thickness of about $200 \mathrm{~m}$ (Fig. 10B).

\section{Ice cap snowlines and surface characteristics from Landsat}

There are no field studies of the mass balance of the glaciers and ice caps on Edgeøya and Barentsøya. The situation is similar to that of most of the relatively inaccessible eastern islands of the archipelago, where only limited work has been carried out (cf. Schytt 1964; Jonsson 1982). By contrast, mass balance measurements extending over a number of years exist for several glaciers in Spitsbergen (Fig. 4B). In the absence of direct measurements of mass balance, satellite imagery can provide basic glaciological information on the location of the snowline and the characteristics of the ice mass surface at a synoptic scale.

In temperate glaciers, where little refreezing of surface meltwater takes place, the position of the late summer snowline is similar to that of the glacier equilibrium line. When ice surface melting takes place in colder environments, meltwater can refreeze at the glacier surface to form superimposed ice. In such cases, the snowline at the end of the melt season lies significantly above the 

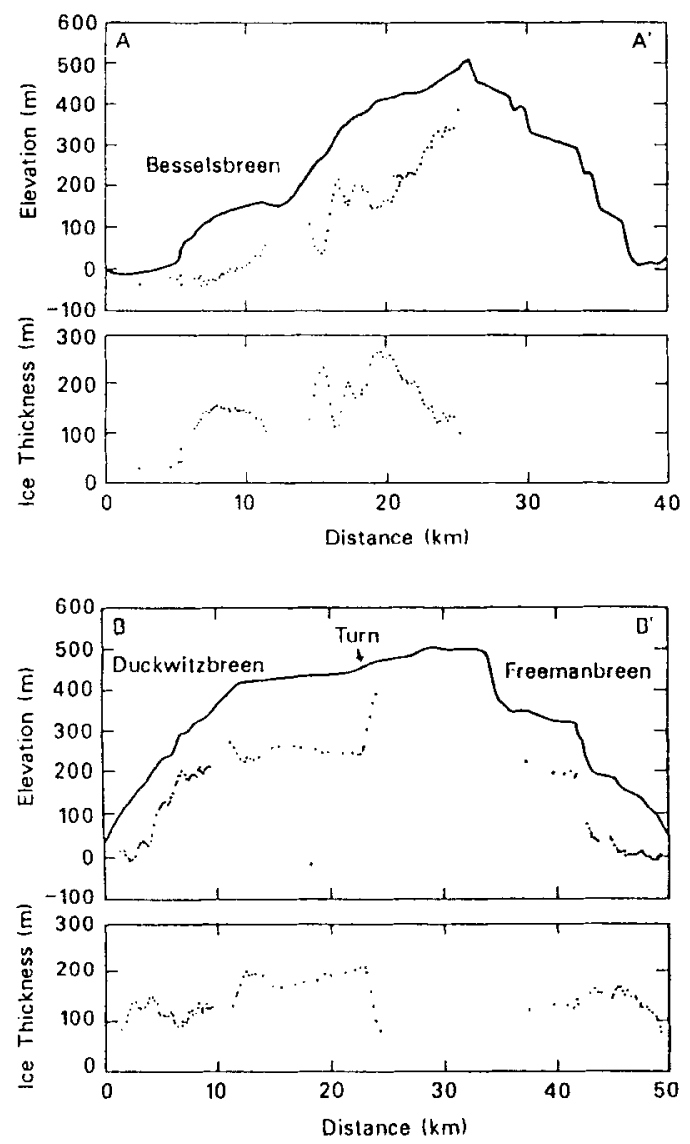

Fig. 10. Two radio-echo sounding profiles across the ice cap of Barentsjøkulen, Barentsøya (located in Fig. 6). (A) Besselsbreen. (B) Duckwitzbreen and Freemanbreen. The elevations of the ice surface and bed are shown.

equilibrium line, because the zone of superimposed ice represents an area of net mass gain to the glacier (Benson 1962; Paterson 1994). The formation of superimposed ice is known, for example, to be a significant component of the mass balance on the ice caps of Vestfonna, Nordaustlandet, and Storøyjøkulen (Jonsson 1982; Palosuo 1987), and of northwest Spitsbergen glaciers (Parrot et al. 1993). Thus, in eastern Svalbard. the mapped snowline is likely to have the same general shape as the ELA, but to be higher in elevation by on the order of about $100 \mathrm{~m}$ (cf. Parrot et al. 1993).

For the ice caps on Edgeøya and Barentsøya, digital images were produced showing the variations of in-band spectral reflectance or albedo recorded on three summer Landsat MSS scenes investigated (Figs. 11 and 12). The trend from lighter colours at low elevations close to the coast, to darker colours at ice cap crests indicates increasing reflectance of the surface. Training areas were selected where snow and bare glacier ice were assumed to be present on the three summer Landsat images acquired. The identification of such areas was based on elevations from Norsk Polarinstitutt topographic maps and aerial photographs from a number of different years. These training areas were then applied to the reflectance data from each image, and the position of the snowline on each was identified. Snowline position for late July/early August was then transferred digitally to topographic datasets derived from Norsk Polarinstitutt 1:100,000 and 1:500,000 maps of the ice caps.

The snowline at the end of July is at about $300 \mathrm{~m}$ on the east side of Edgeøyjøkulen, and 50 to $100 \mathrm{~m}$ higher on its western side. The ice caps of Digerfonna and Storskavlen, further west in Edgeøya (Fig. 1), have higher snowlines at about $450 \mathrm{~m}$. A similar pattern is present on Barentsjøkulen, where the snowline elevation is about $350 \mathrm{~m}$ on the eastern flank of the ice cap and over $400 \mathrm{~m}$ in elevation on the west side. It appears that there is a general asymmetry in snowline altitude on the two islands, with lower values on the eastern side of the ice caps. Liestøl (1993) reports a similar trend in equilibrium line altitude (ELA) across the Svalbard archipelago, with the lowest ELA elevations in the southeast. He interprets this to represent a trend towards greater precipitation in the southeast of Svalbard caused by relatively moisture-laden southeasterly winds (Liestøl 1993). This suggestion is supported by the winter accumulation measurements of Schytt (1964) over the ice caps of Nordaustlandet, where accumulation was highest on the southeast facing flanks of the $8200 \mathrm{~km}^{2}$ ice cap of Austfonna.

An advantage of the approach to satellite mapping of snowline position used in this paper is that it provides a single methodology applied consistently at a synoptic scale across Edgeøya and Barentsøya. However, three caviats should be attached to the data. First, they are from late July and early August rather than from the termination of the melt season at about the end of August, and thus represent a minimum elevation for the snowline at the end of the ablation season. Second, they are for a single year, 1980, in which net mass balance on northwest Spitsbergen glaciers was slightly more negative than the 1967 


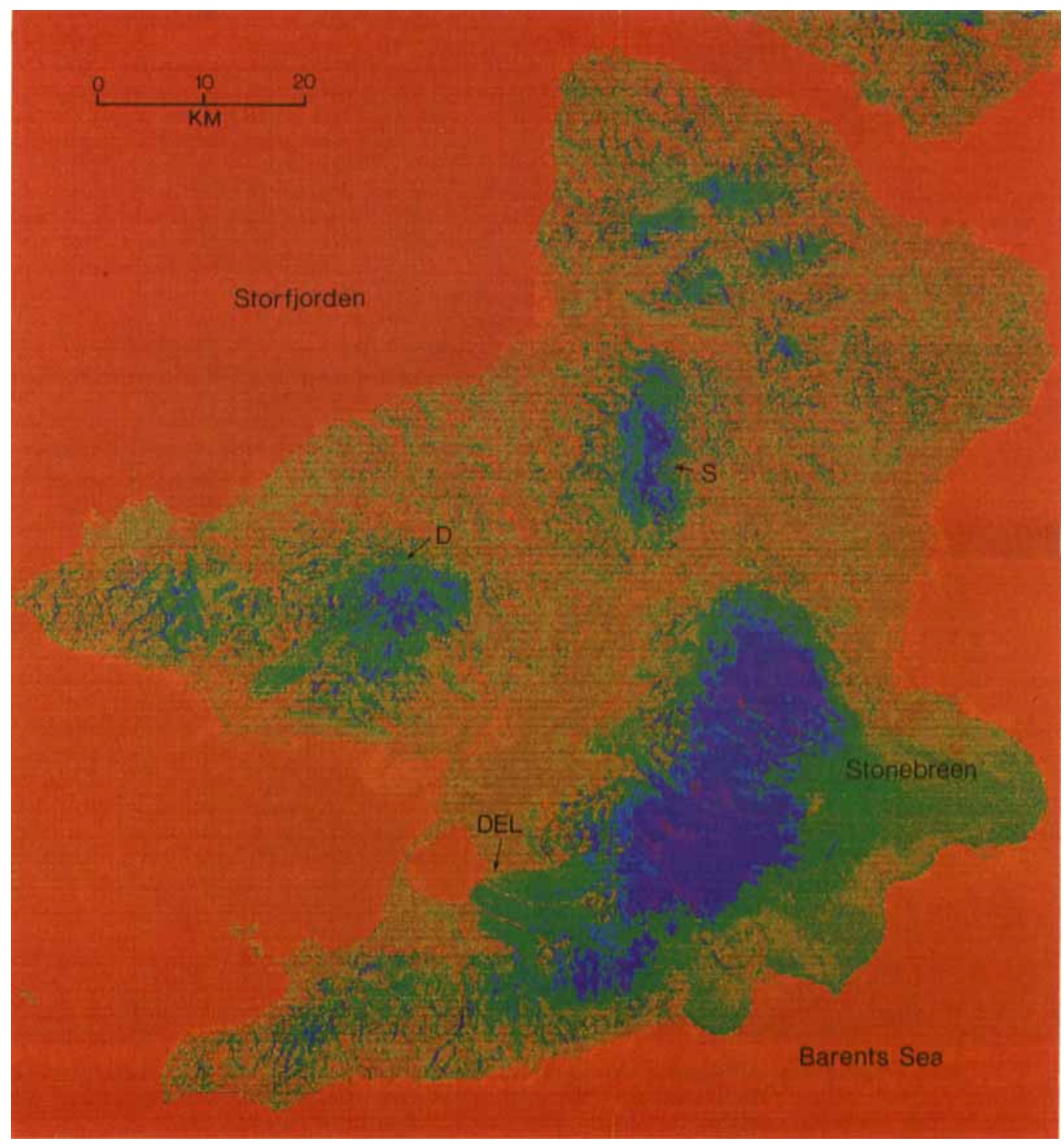

Fig. 11. A digitally enhanced image of Edgeøya, showing in-band reflectance data from band $3(0.7-0.8 \mu \mathrm{m})$ of the Landsat MSS (path/row 226/004. 29 July 1980). D is Digerfonna, DEL is Deltabreen and S is Storskavlen. The dark areas (blue and purple) represent the high reflectance snow-covered surface on the upper parts of the major ice caps. The snowline occurs-at the outer boundary of these dark areas. The largest area of snow cover is found on Edgeøyjøkulen (Fig. 1).

88 average (Hagen \& Liestøl 1990). Third, no systematic relationship for the difference between the late summer snowline and ELA, taking account of net accumulation of superimposed ice, has been established for Svalbard ice masses.

\section{Landsat analysis of glacier-derived meltwater plumes}

Plumes of turbid meltwater are observed in marine waters at the margins of many tidewater glaciers (Fig. 2). These streams, and their load of suspended sediments, can come either directly from glacier hydrological systems or from proglacial meltwater streams if adjacent unglaciated land is present. For glaciers ending in tidewater, and particularly those larger ice masses where little or no rock outcrop and hence subaerial sediment source is present, a principal source of turbid water is the basal drainage system. In these 
Fig. 12. A digitally enhanced image of Barentsøya, showing in-band reflectance data from band $3(0.7-0.8 \mu \mathrm{m})$ of the Landsat MSS (path/row 229/003, 1 August 1980). The dark areas (blue, purple and magenta) represent the high reflectance snow-covered surface on the upper part of Barentsjøkulen. The snowline occurs at the outer boundary of these dark areas.

situations it is only from subglacial locations that suspended sediments are available for entrainment. When these turbid fresh water streams exit confining tunnels at tidewater ice cliffs. buoyancy effects mean they will rise to the surface (Powell 1990), and are observable on aerial photographs and satellite imagery. The glaciological significance of these turbid plumes is that they provide an indication that water is present at the base of the parent ice mass, and that the glacier is therefore melting over at least a part of its bed (cf. Dowdeswell \& Drewry 1989; Pfirman \& Solheim 1989; Bamber \& Dowdeswell
1990). This, in turn, gives a preliminary indication of glacier thermal structure.

Digital enhancement of the blue band (0.5$0.6 \mu \mathrm{m})$ on Landsat images of Edgeøya and Barentsøya was used to record the presence of turbid meltwater plumes around their marine margins (Figs. 13 and 14). Water is most transparent at these wavelengths, and the presence of suspended sediments in the near surface is shown by pixels which are significantly brighter than those of clear water. Further, turbid water can be distinguished from sea-ice floes because the latter will appear bright at in all four Landsat MSS 
bands (i.e. $0.5-1.1 \mu \mathrm{m}$ ), whereas the effect of suspended solids becomes progressively less apparent with increasing wavelength. The locations of plumes identified from Landsat imagery of Svalbard has also been compared with aerial photographic evidence (Dowdeswell 1984) and water sampling programmes (Pfirman \& Solheim 1989) to confirm such an interpretation.

Turbid meltwater plumes are observed in the waters around Edgeøya and Barentsøya on digitally enhanced Landsat MSS imagery (Figs. 13 and 14). The plumes are derived from both subaerial glacier-fed rivers, and from the drainage systems of the glaciers and ice caps of the two islands. Aerial photographs of the ice-ocean interface around Edgeøya and Barentsøya confirm the interpretation of the Landsat dataset, and also show turbid meltwaters derived from both ice marginal and subglacial streams, dependent on the particular setting of individual outlet glaciers. Having entered the marine environment, the plumes tend to follow the coast in a band of turbid water no more than a few kilometres wide (Figs. 13 and 14). This is presumably associated with longshore currents, the instantaneous directions of which can be defined on the basis of plume form. For example, current direction is clearly southward along the east coasts of Edgeøya and Barentsøya in Figs. 13 and 14.

A closer investigation of the brightness characteristics of the turbid plumes shows that they undergo a decay with distance from the point source of the sediment-rich waters. This is associated with a combination of sediment deposition from the plume, and its mixing with marine waters of normal ocean salinity and turbidity. A digitally enhanced part-scene of the northern part of Edgeøyjøkulen and adjacent bare land illustrates this (Fig. 15). Several relatively bright point sources for suspended sediment plumes can be seen linked to (i) glacier-fed subaerial meltwater streams and (ii) subglacial drainage from beneath the ice cap. The extensive tidewater ice cliffs of Stonebreen, in excess of $40 \mathrm{~km}$ in length, provide the clearest examples of turbid plumes derived from subglacial drainage. Here there is no subaerial source for the sediments within the water column. This finding implies that at least a part of the bed of Edgeøyjøkulen is at the pressure melting point and that a basal drainage system exists, including channels with significant water discharge. The distribution of arrows showing the main point sediment sources in Figs. 13-15 indicates that most of the major ice-cap outlet glaciers have turbid marginal and/or basal drainage systems.

\section{Summary and conclusions}

The ice caps on Edgeøya and Barentsøya are the least well known in Svalbard. There are no existing field studies of either the ice thickness or the mass balance of these glaciers and ice caps, which cover a total area of over $2800 \mathrm{~km}^{2}$. The following main points can be made:

(1) Several of the ice-cap outlet glaciers on Edgeøya and Barentsøya are known to surge (Table 2; Fig. 3; Lefauconnier \& Hagen 1991), and different drainage basins within the ice caps behave as dynamically separate units. The tidewater ice cliffs of eastern Edgeøya are over $80 \mathrm{~km}$ long (Figs. 1 and 2), and produce small tabular icebergs (Dowdeswell 1989).

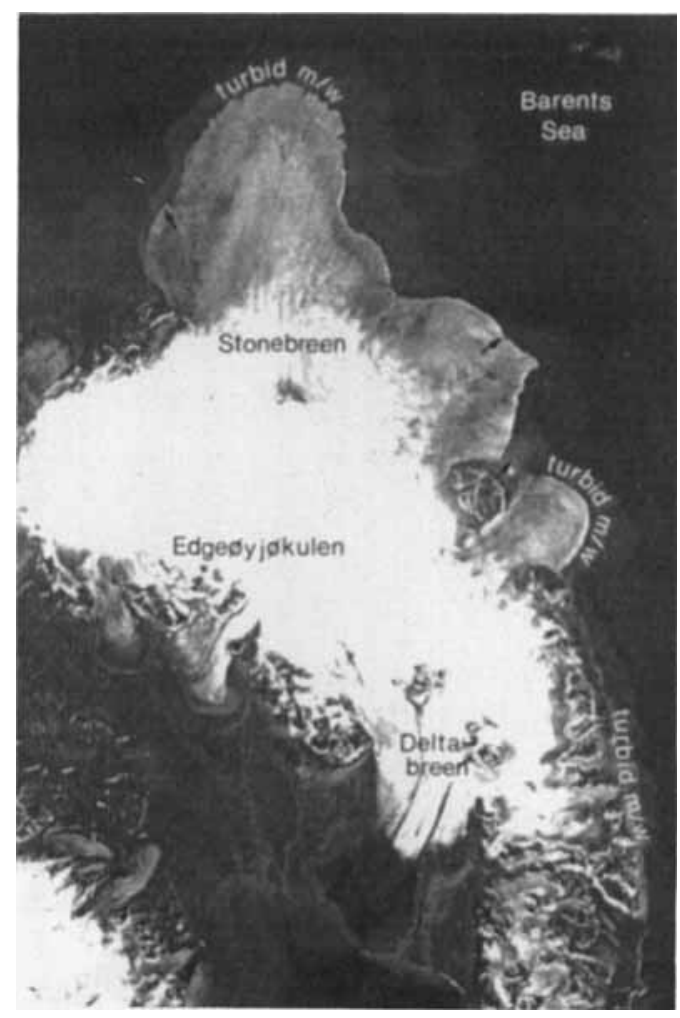

Fig. 13. Turbid meltwater plumes on digitally enhanced Landsat MSS band $1(0.5-0.6 \mu \mathrm{m})$ imagery of Edgeøya (path/row 226/ 004,29 July 1980). Arrows highlight the point sources of the major plumes. The imagery is located in Fig. 6. 


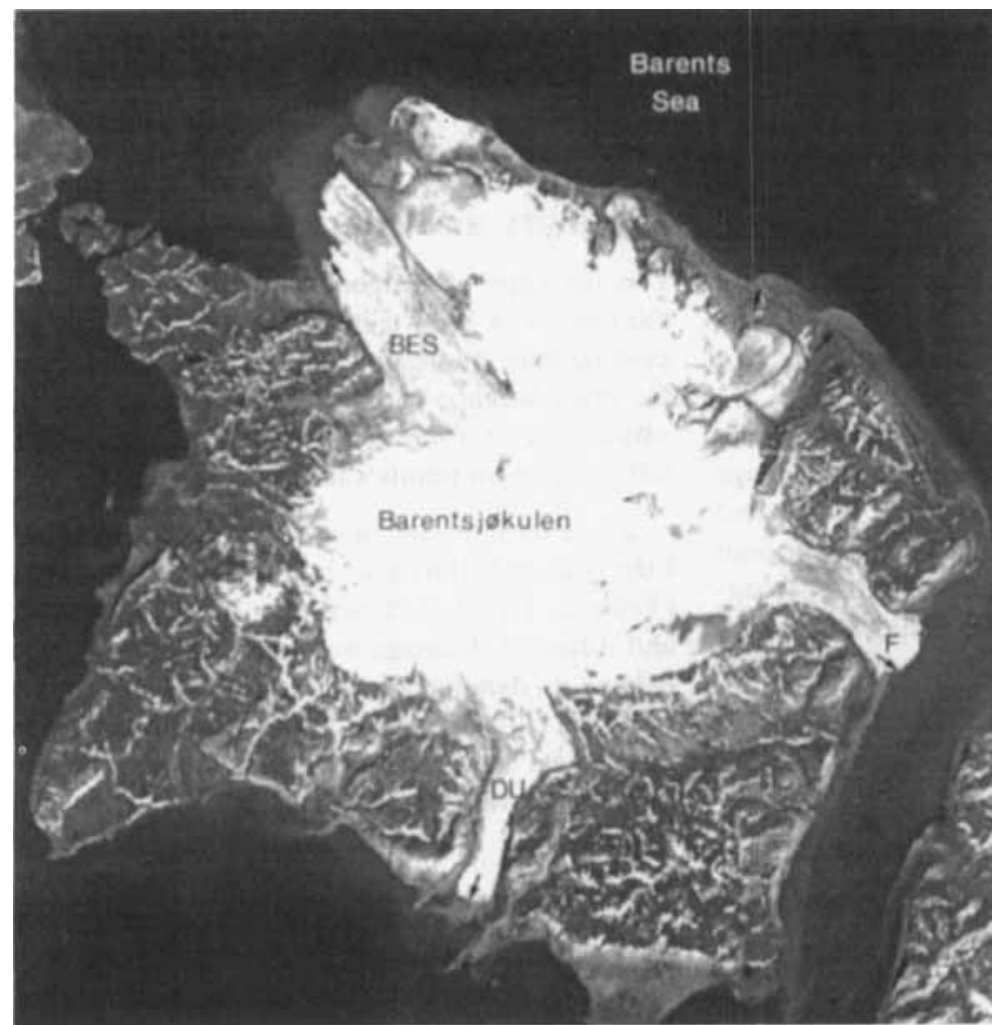

Fig. 14. Turbid meltwater plumes on digitally enhanced Landsat MSS band $1(0.5-0.6 \mu \mathrm{m})$ imagery of Barentsøya (path/row 229/003, 1 August 1980). Arrows highlight the point sources of the major plumes. The imagery is located in Fig. 6.

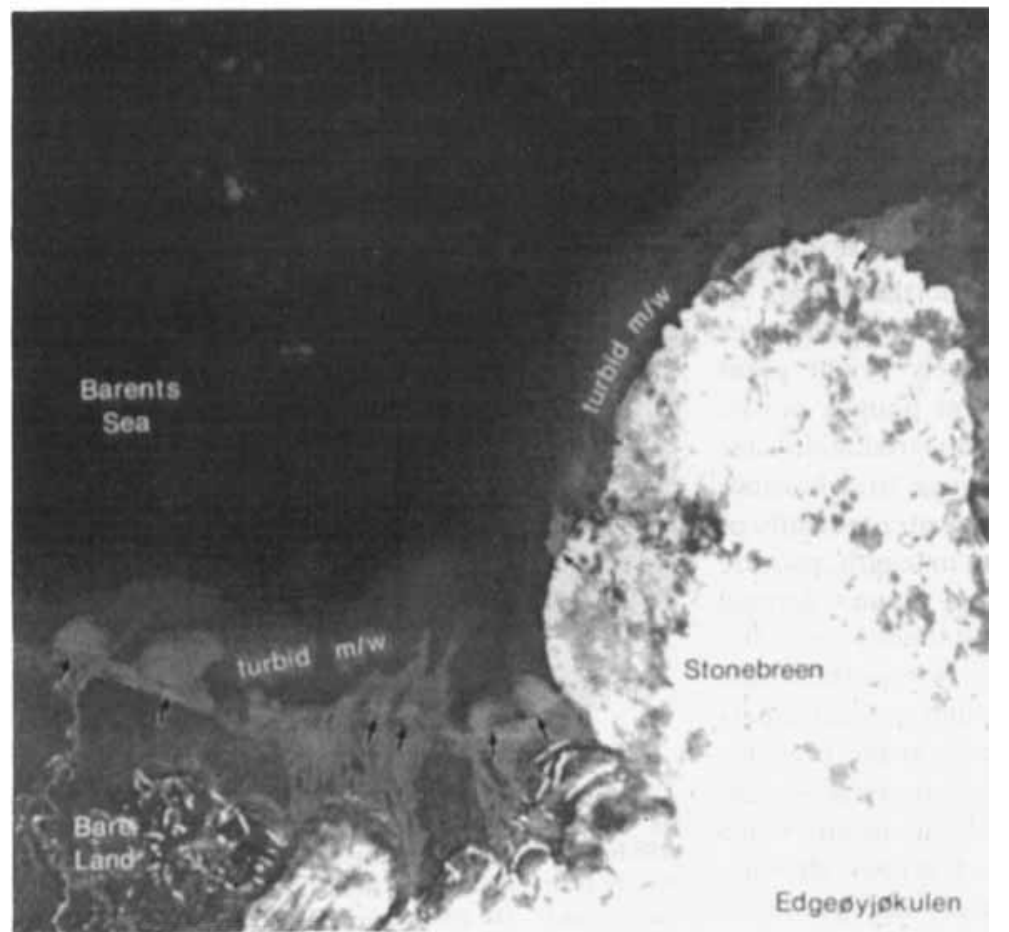

Fig. 15. Digitally enhanced Landsat MSS band $1(0.5-$ $0.6 \mathrm{rm}$ ) image of part of Stonebreen and adjacent bare land on Edgeøya, located in Fig. 6. Several point sources of turbid meltwater are indicated by arrows, and the decay in plume brightness with distance from these sources can be seen. Dark patches over the ice cap are clouds. Landsat path/ row 229/003, acquired 1 August 1980. 
(2) Terminus advances during surging have punctuated a more general retreat from Little Ice Age moraines, probably linked to Twentieth Century climate warming and mass balance change (Fig. 4).

(3) Airborne radio-echo sounding at $60 \mathrm{MHz}$ along $340 \mathrm{~km}$ of flight track on the ice caps has provided ice thickness and elevation data (Figs. $5-10)$. Ice is grounded below sea level to about $20 \mathrm{~km}$ inland from the tidewater terminus of Stonebreen. Ice thickens from $<100 \mathrm{~m}$ close to the margins, to about $250 \mathrm{~m}$ in the interior of Edgeøyjøkulen. The maximum ice thickness measured on Barentsjøkulen is $270 \mathrm{~m}$.

(4) Landsat MSS images of the two islands, calibrated to in-band reflectance values, allow synoptic examination of snowline position in late July/early August (Figs. 11 and 12). Snow and bare glacier ice were identified, and images were digitally stretched and enhanced. The snowline was at about $300 \mathrm{~m}$ on the east side of Edgeøyjøkulen, and 50-100 $\mathrm{m}$ higher to the west. Snowlines were at approximately $450 \mathrm{~m}$ on Digerfonna and Storskavlen. On Barentsjøkulen the snowline was $350 \mathrm{~m}$ above sea level on its eastern flank and over $400 \mathrm{~m}$ on the west. This asymmetry suggests greater precipitation on the east side of the ice caps.

(5) Turbid meltwater plumes are observed in the waters offshore of several tidewater ice masses in Edgeøya and Barentsøya on digitally enhanced Landsat MSS imagery (Figs. 13-15). This implies that at least parts of the beds of these ice masses are at the pressure melting point and that a basal drainage system is present, including channels with significant water discharge.

Acknowledgements. - We thank Norsk Polarinstitutt for cooperation with our airborne programme in 1986, and for permission to reproduce aerial photographs from their collection. A. D. Diament and A-M. Nuttall assisted with processing of digital satellite images. Funding for part of this work came from EC EPOCH Grant CT91-0035.

\section{References}

Bamber, J. L. \& Dowdeswell, J. A. 1990: Remote-sensing studies of Kvitøyjøkulen, an ice cap on Kvitøya, north-east Svalbard. J. Glaciol. 36, 75-81.

Benson, C. S. 1962: Stratigraphic studies in the snow and firn of the Greenland Ice Sheet. Snow, Ice and Permafrost Research Establishment, Res. Rep. $70.93 \mathrm{pp}$.

Dowdeswell, J. A. 1984: Remote sensing studies of Svalbard glaciers. Ph.D. Thesis, University of Cambridge. $250 \mathrm{pp}$.

Dowdeswell. J. A. 1986: Drainage-basin characteristics of Nordaustlandet ice caps. Svalbard. J. Glaciol. 31, 31-38.
Dowdeswell, J. A. 1989: On the nature of Svalbard icebergs. J. Glaciol. 35, 224-234.

Dowdeswell, J. A. \& Collin, R. L. 1990: Fast-flowing outlet glaciers on Svalbard ice caps. Geol. 18. 778-781

Dowdeswell, J. A \& Drewry, D. J. 1989: The dynamics of Aust fonna, Nordaustlandet, Svalbard: surface velocities. mass balance and subglacial meltwater. Ann. Glaciol. 12, 3745.

Dowdeswell, J. A., Drewry, D. J.. Liestøl. O. \& Orheim. O. 1984: Airborne radio echo sounding of sub-polar glaciers in Spitsbergen. Norsk Polarinst. Skr. 182.41 pp.

Dowdeswell. J. A.. Drewry, D. J. Cooper, A. P. R.. Gorman. M. R.. Liestøl, O. \& Orheim, O. 1986: Digital mapping of the Nordaustlandet ice caps from airborne geophysical investigations. Ann. Glaciol. 8, 51-58.

Dowdeswell, J. A., Hagen, J. O. \& Hamilton, G. S. 1991: The duration of the active phase on surge-type glaciers: contrasts between Svalbard and other regions. J. Glaciol. 37. 388-400.

Gorman, M. R. \& Cooper, A. P. R. 1987: A digital radio echo sounding and navigation recording system. Ann. Glaciol. 9,8184.

Hagen, J. O. 1987: Glacier surge at Usherbreen. Svalbard. Polar Res. 5, 239-252.

Hagen, J. O. \& Liestøl, O. 1990: Long-term glacier massbalance investigations in Svalbard, 1950-88. Ann. Glaciol. 14. 102-106.

Hagen, J. O., Liestøl, O., Roland, E. \& Jørgensen, T. 1993: Glacier Atlas of Svalbard and Jan Mayen. Norsk Polarinst. Medd. 129. $141 \mathrm{pp}$.

Jonsson. S. 1982: On the present glaciation of Storöya Svalbard. Geogr. Ann. 64A, 53-79.

Lamont, J. 1861: Seasons with the Sea Horses or Sporting Adventures in the Northern Seas. Hurst and Blackett. London.

Lefauconnier, B. \& Hagen, J. O. 1991: Surging and calving glaciers in eastern Svalbard. Norsk Polarinst. Medd. 116. 130 pp.

Liestø1, O. 1993: Glaciers of Svalbard. Norway. U.S. Geological Survey, Professional Paper 1386-E-5, E127-151.

Markham, B. L. \& Barker, J. L. 1986: Landsat MSS and TM post-calibration dynamic ranges, exoatmospheric reflectances and at-satellite temperatures. Landsat Technical Notes No. 1. EOSAT

Palosuo, E. 1987: Ice layers and superimposition of ice on the summit and slope of Vestfonna, Svalbard. Georg. Ann. 69. A. 289-296.

Parrot, J. F., Lyberis, N., Lefauconnier, B. \& Manby. G. 1993; SPOT multispectral data and digital terrain model for the analysis of ice-snow fields on Arctic glaciers. Int. J. Remole Sens. 14, 425-440.

Paterson, W. S. B. 1994: The Physics of Glaciers (3rd Edition) Pergamon, Oxford. $480 \mathrm{pp}$.

Pfirman, S. L. \& Solheim, A. 1989: Subglacial meltwater discharge in the open-marine tidewater glacier environment: observations from Nordaustlandet, Svalbard archipelago. Mar. Geol. 86, 265-281.

Powell, R. D. 1990: Glacimarine processes at grounding-line fans and their growth to ice-contact deltas. In Dowdeswell, J. A. \& Scourse, J. D., (eds.): Glacimarine Environments: Processes and Sediments, Geol. Soc. Lond. Spec. Publ. 53. 53-73.

Robinove, C. J. 1982: Computation with physical values from Landsat digital data. Photogramm. Eng. Remote Sensing 48. 781-784.

Schytt, V. 1964: Scientific results of the Swedish Glaciological 
Expedition to Nordaustlandet. Spitsbergen. 1957 and 1958. Geogr. Ann. 46, 243-281.

Schytt, V. 1969: Some comments on glacier surges in eastern Svalbard. Can. J. Earth Sci. 6, 867-873.
Vinje. T. 1985: The physical environment of the western Barents Sea: drift, composition, morphology and distribution of the sea ice fields in the Barents Sea. Norsk Polarinst. Skr. 179C. $26 \mathrm{pp}$. 